\title{
Techno-Enviro-Economic Assessment of a Solar Powered Cooler for Cauliflower Storage in Nanded District, India
}

\author{
Jimena Díaz $^{\text {** }}$, Prashant Govande ${ }^{2 *}$, Kapil Narwal ${ }^{3}$, Paul G. O'Brien ${ }^{3}$ \\ ${ }^{1}$ Department of Environmental Sciences, Life Sciences Division, University of Guanajuato \\ Ex Hacienda El Copal, km. 9 Irapuato-Silao Highway; P.C. 36824, Irapuato, Guanajuato, Mexico \\ j.diazespana@ugto.mx \\ ${ }^{2}$ Shri Guru Gobind Singh Ji Institute of Engineering and Technology, \\ Vishnupuri, Nanded, India \\ 2018bpr039@sggs.ac.in \\ *These two authors contributed equally to this work \\ ${ }^{3}$ Department of Mechanical Engineering, Lassonde School of Engineering, York University \\ 4700 Keele Street, Toronto, Ontario, M3J 1P3, Canada \\ knarwal@yorku.ca, paul.obrien@lassonde.yorku.ca
}

\section{Extended Abstract}

Independent farmers throughout India grow and sell crops to generate income. However, depending on market conditions, many farmers are forced to either sell their produce at unreasonably low prices, or to allow it to perish. In fact, the United Nations Food and Agriculture Organization (FAO) has estimated that more than $40 \%$ of the produce in India is wasted every year, which represents a value of US\$14 Billion (12.42 billion euro) annually [1]. These problems associated with fair prices and food wastes could be substantially alleviated if independent farmers in India had access to cold storage. Herein we design and evaluate solar powered coolers for produce storage in India. As a case study we select cauliflower farming in Nanded district, India. Cauliflower is a valuable source of nutrients including protein, vitamin $\mathrm{B}$, vitamin $\mathrm{C}$, and is an important wither vegetable in India.

A solar powered cooler is designed to store half of the cauliflower harvested from a land area of 10 acres at a temperature of $10{ }^{\circ} \mathrm{C}$ for 20 days. The volume of the cooler required to store the cauliflower is $38.2 \mathrm{~m}^{3}$. To estimate the cooling load, the heat of respiration from the cauliflower, the heat of infiltration through the cooler doors, the heat gain through the cooler walls, and the metabolic heat gain from working in the cooler were taken into consideration. The cooling load, including a $20 \%$ safety factor, is $\sim 6,200 \mathrm{~kW}$.

Two different options are considered to provide power to meet the required cooling load: an air conditioner equipped with CoolBot Technology [2], powered by photovoltaic (PV) cells, and a solar-powered absorption-based cooling system. The average solar insulation throughout India ranges from $4-7 \mathrm{kWh} / \mathrm{m}^{2} \cdot$ day, providing $1,500-2,000$ hours of sunshine per year. The use of solar energy minimizes greenhouse gas emissions and enables the cooler to be operated in remote locations.

The PV-based cooler is comprised of monocrystalline silicon-based PV panels, a charge controller, $12 \mathrm{~V} 200 \mathrm{AH}$ Li-ion batteries, an AC unit, and the CoolBot microcontroller. The absorption-based solar power cooler comprises a condenser, evaporator, absorber, pump, heat exchanger, a hot water storage tank, and uses an ammonia-water refrigerant pair [3]. The thermal energy used to power the absorption-based cooler is comprised of an evacuated tube collector (ETC) system, from Solaris.

A techno-enviro-economic assessment of the PV- and absorption-based cooler is performed using publicly available articles and information [4-7]. The area of the PV panels is estimated to be $65.5 \mathrm{~m}^{2}$, whereas the area of the ETC system is $140 \mathrm{~m}^{2}$. The emissions from the PV-based cooling system is estimated as $45,000 \mathrm{kgCO}_{2 \mathrm{eq}}$, whereas that for the absorption-based cooling system is $15,900 \mathrm{kgCO}_{2 \mathrm{eq}}$. The estimated costs of the PV-and absorption based solar powered cooling system is 15,600 and 24,3000 CAD, respectively. Payback periods of less than a few years are estimated and the results suggests that a shared solar powered cooler amongst farmers working a 10 acre plot of land can be a valuable asset, especially considering additional governmental incentives may be available. 


\section{References}

[1] R. Nigam, S. Sharma, "Food Waste Management," Amity Journal of Energy \& Environmental Studies, vol. 3, no. 2, pp $1-8,2017$.

[2] E. M. Karithi, Evaluation of the efficacy of Coolbot ${ }^{\mathrm{TM}}$ cold storage technology to preserve quality and extend shelf life of mango fruits. Horticulture of the University of Nairobi - Department of Plant Science and Crop Protection, 2016.

[3] A. Hmida, N. Chekir, A. Laafer, M. E. Slimani, A. B. Brahim, "Modeling of cold room driven by an absorption refrigerator in the South of Tunisia: A detailed energy and thermodynamic analysis," J. Clean. Prod., vol. 211, pp. 1239-1249, 2019.

[4] M. Milousi, M. Souliotis, G. Arampatzis, S. Papaefthimiou, "Evaluating the environmental performance of solar energy systems through a combined life cycle assessment and cost analysis" Sustainability., vol. 11, 2539, 2019.

[5] L. Tschümperlin, P. Stolz, F. Wyss, R. Frischknecht, Life cycle assessment of low power solar inverters (2.5 to 20 kW), Swiss Federal Office of Energy SFOE, 2016.

[6] M. L. Carvalho, A. Temporelli, P. Girardi, Life cycle assessment of stationary storage systems within the Italian electric network, Energies, vol. 14, 2047, 2021.

[7] Y. Hang, M. Qu, R. Winston, L. Jiang, B. Widyolar, H. Poiry, Experimental based energy performance analysis and life cycle assessment for solar absorption cooling system at University of Californian, Merced, Energy Build., 82, 2014, 746-757. 